\title{
Do Highly Aggressive Bacteria Cause Dental Caries in Some Children?
}

\author{
Mohammed Karimi DMD* \\ Department of Pediatric Dentistry, Sepideh Dental Clinic Iran \\ *Corresponding author: Mohammed Karimi, Department of Pediatric Dentistry, Sepideh Dental Clinic, Iran
}

\section{Short Communication}

Perhaps the question that many pediatric dentists may have is whether a group of bacteria play an important role in the development of dental caries in children. The results of the new research that was carried out at Umea University in Sweden, can answer this question. Researchers at Umea University discovered a new issue in relation to cariogenic different types of Streptococcus Mutans bacteria. They also investigated the adhesion performance of bacteria on children teeth with common caries and increased risk of dental caries. The results of the study, published in the EBio Medicine Journal, could lead to the development of a better way to identify high-risk patients and treat their caries. Dental caries is one of the diseases of the lifestyle, often due to poor oral and dental health and nutritional habits, which results in decreasing the level of acidic $\mathrm{pH}$ in the mouth [1-3]. The more likely we will see the development of dental caries if the teeth are exposed to a low salivary $\mathrm{pH}$ in a long period of time [4]. Low PH levels have a harmful effect on enamel; increases the growth of acid-producing bacteria, such as Streptococcus Mutans [5-8]. In this five-year study, the saliva of a large number of children was analyzed, and dental health care of these children was supervised. The researchers proved that high-risk children have more invasive types of cariogenic bacteria, and the adherence of these bacteria makes them more aggressive and more susceptible to survival. However, the results of this study showed that in some high-risk children at high risk of rot, there are certain types of highly invasive bacteria, S Mutans, which can cause caries irrespective of lifestyle. These invasive strains have unique sticky proteins called SpaP and $\mathrm{Cnm}$, which increase the ability of the bacteria to survive in the antibacterial saliva of the mouth.

One out of five Swedish children has such a dangerous strain and is at high risk for dental caries. These children do not respond to traditional caries prevention or treatment, and their lifestyle variables cannot predict the risk of caries [8]. Chronic dental caries and loose teeth are also risk factors for systemic diseases, such as cardiovascular disease [9,10]. Overall, $70 \%$ of tooth loss is due to tooth decay $[11,12]$. This article explains how up to half of the highrisk children are threatened by highly invasive types of S. Mutans. These species can also increase the risk of cardiovascular disease and other systemic diseases in the future. Highly aggressive types also differ in terms of adhesion performance. Through biochemical studies, researchers discovered the association between the binding of SpaP and Cnm proteins and their adherence to saliva and DMBT1 protein in saliva [8]. They also showed that higher binding ability has led to an increase in dental caries over a five-year study period. In the end, to conclude this article, Dr. Stromberg believes other high-risk children have a genetic defect in their salivary receptors for bacteria, and the damaged genes may include the same genes that are involved in autoimmune diseases. But it is still important to emphasize that caries is affected by oral and dental health habits in many low to moderate risk people [8]. On the other hand, from new information on the identified types of bacteria, and their manner to start tooth decay, it can be used to improve dental care. Furthermore, the presence of these bacteria can be applied as biological markers for the early detection of high-risk patients. Moreover, their adhesion performance also can be considered as new targets for treatments [8].

\section{References}

1. WHO (2012) World Health Organization WHO Oral health Fact Sheet 318.

2. P Moynihan (2005) The interrelationship between diet and oral health. Proceedings of the Nutrition Society 64(4): 571-580.

3. Matthew P Flipsen, Yevgeniy Zenchenko (2017) Nutrition for oral health and oral manifestations of poor nutrition and unhealthy habits, General Dentistry, pp. 36-43.

4. N Takahashi (2005) Microbial Ecosystem in the Oral Cavity: Metabolic Diversity in an Ecological Niche and Its Relationship with Oral Diseases. International Congress Series 1284: 103-112. 
5. Robert Matsui, Dennis Cvitkovitch (2010) Acid tolerance mechanisms utilized by Streptococcus Mutans. Future Microbiol 5(3): 403-417.

6. Riva Touger Decker, Cor van Loveren (2003) Sugars and dental caries. The American Journal of Clinical Nutrition 78(4): 881-892.

7. V Law, WK Seow, G Townsend (2007) Factors influencing oral colonization of Mutans streptococci in young children. Australian Dental Journal 52(2): 93-100.

8. N Stromberg, A Esberg, N Sheng, L Marell, C Kallestal (2017) Geneticand Lifestyle-dependent Dental Caries Defined by the Acidic Prolinerich Protein Genes PRH1 and PRH2. EBio Medicine 26: 38-46.
9. Hartsfield JK (1994) Premature Exfoliation of Teeth in Childhood and Adolescence. Advances in pediatrics 41: 453.

10. Sanchez P, Everett B, Salamonson Y, Ajwani S, Bhole S, et al. (2017) Oral health and cardiovascular care: Perceptions of people with cardiovascular disease. PLoS ONE 12(7): 0181189.

11. Brown LJ, Oliver RC, Loe H (1989) Periodontal diseases in the US in 1981: prevalence, severity, extent, and role in tooth morality. Journal of Periodontology 60(7): 363-370.

12. (1992) Enough to make you sick: how income and environment affect health. National Health Strategy, Melbourne, pp.144.
To Submit Your Article Click Here: Submit Articte

DOI: $10.32474 /$ IPDOAJ.2019.03.000153

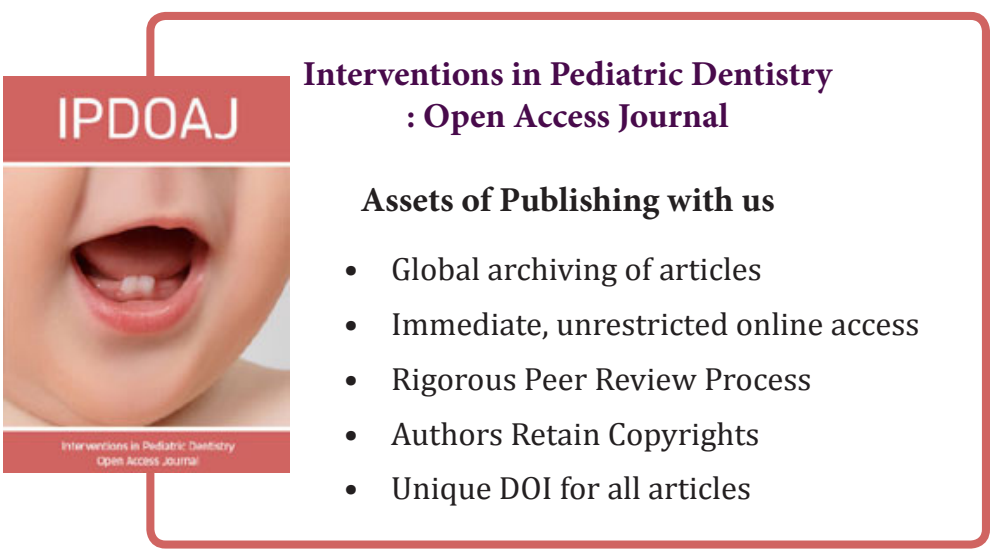

